\title{
II. ARTYKUŁY
}

\section{Niektóre ograniczenia swobody zawierania malżeństw $w$ rzymskim prawie poklasycznym na przykladzie dowódców wojskowych $w$ stopniu ,dux”}

\author{
Einige Beschränkungen der EheschlieBungsfreiheit \\ im römischen nachklassischen Recht am \\ Beispiel der militärischen Befehlshaber im Rang $d u x$
}

1. Wstẹp. Zagadnienia ogólne: zakres chronologiczny pracy; stopień oficerski dux; zakazy małżeńskie wobec wojskowych. 2.1. Ustawy późnoantyczne: konstytucja Konstantyna I Wielkiego z 336 r. oraz Nowela Marcjana z 454 r. (CTh IV, 6, $3=$ C V, 27, 1; Novella Marciani $4=\mathrm{C} \mathrm{I}, 14,9 ; \mathrm{C} \mathrm{V}, 5,7) \mathrm{i}$ ich analiza. 2.2. Stopniowe znoszenie zakazów pod wplywem chrześcijaństwa $w$ VI w. 2.3. Przestrzeganie ograniczeń $w$ doborze małzonka przez dowódców w stopniu dux. 3.1. Problem zakazu małżeństw między chrześcijanami a Żydami i heretykami. 3.2. Zakaz małżeństw chrześcijan z Żydami: konstytucja Gracjana, Walentyniana II i Teodozjusza I z 388 r. (CTh III, 7, 2=CTh IX, 7, $5=$ C I, 9, 6) i jej analiza. 3.3. Obowiązywanie konstytucji z $388 \mathrm{r}$. wobec dowódców w stopniu dux. 3.4. Przyczyny braku zakazu małżeństw między katolikami a heretykami w prawie rzymskim. 4.1. Zakaz małżeństw Rzymian z barbarzyńcami. Konstytucja Walentyniana I i Walensa z ok. $370 \mathrm{r}$. (CTh III, 14, 1) i stosowanie jej wobec dowódców wojskowych. 4.2. Zagadnienie zakresu obowiązywania zakazu małżeństw mieszanych określonego w noweli Justyniana I (Novella lustiniani 154). 5. Wnioski.

1. Einleitung. Allgemeines Fragen: Chronologischer Rahmen der Arbeit; Offizierrang dux, Eheverbote für Militärpersonen. 2.1. Spätantike Gesetze: Verfassung von Konstantin I. dem Großen aus dem Jahre 336. und Marcjans Novelle aus dem Jahre 454 (CTh IV, 6, 3 = C V, 27, 1; Novella Marciani $4=\mathrm{C} \mathrm{I}, 14,9 ; \mathrm{C} \mathrm{V}, 5,7)$ und ihre Analyse. 2.2. Allmähliche Aufhebung der Verbote unter dem Einfluss des Christentums im VI. Jh. 2.3. Beachten der Beschränkungen bei der Wahl des Ehepartners von den Befehlshabern im Rang dux. 3.1. Das Problem des Eheverbots zwischen Christen und Juden oder Häretikern. 3.2. Eheverbot zwischen Christen und Juden: Verfassung von Gratian Valentinian dem II. und Theodosius dem I. aus dem Jahre 338 in ihre Analyse. 3.3. Geltung von der Verfassung aus dem Jahre 338 für Befehlshaber im Rang dux. 3.4. Ursachen des Mangels an Eheverbot zwischen Katholiken und Häretikern im römischen Recht. 4.1. Eheverbot zwischen Römern und Barbaren. Verfassung von Valentinian dem 1 . und Valens etwa aus dem Jahre 370 und ihre Anwendung unter Befehlshabern. 4.2. Frage des Geltungsbereichs vom Mischeheverbot in der Novelle Iustinianis. 5. Schlußfolgerungen. 
1. Przedstawiona poniżej problematyka ograniczeń swobody zawierania małżeństw na przykladzie dowódców wojskowych w stopniu dux dotyczy okresu od pojawienia się tego stopnia wojskowego pod koniec III w., do czasów Justyniana I Wielkiego (lata 527--565)․ Tekst powstał z inspiracji badań prowadzonych nad statusem oficerów $w$ tym stopniu $w$ prawie publicznym.

$\mathrm{Na}$ temat stopnia oficerskiego dux brak jest opracowania monograficznego $^{2}$. Istniejące studia mają charakter fragmentaryczny, natomiast związane $z$ tematem uwagi rozproszone są $w$ pracach o charakterze ogólnym, poświęconych historii późnoantycznej wojskowości ${ }^{3}$. W literaturze nie starano się analizować pozycji prawnej duces w prawie prywatnym. Niniejszy szkic jest próbą omówienia kilku ograniczeń swobody zawierania małżeństw w rzymskim prawie poklasycznym na przykladzie dowódców tej rangi.

Dux jako oficerski stopień wojskowy pojawil się za Dioklecjana i upowszechnił się za Konstantyna Wielkiego na przelomie III i IV w. Terytorialny zakres kompetencji tych oficerów najczęściej był ograniczony do jednej prowincji. W prowincjach nadgranicznych oficerowie ci tytułowani byli poczatkowo dux limitis i $\mathrm{z}$ reguły dowodzili większymi oddziałami wojska niż dowódcy tego samego stopnia $w$ prowincjach wewnętrznych państwa. Podlegały im początkowo wojska prowincjonalne - limitanei, a najpóźniej - od końca V w. - wszystkie wojska stacjonujące w prowincji. Od końca IV w. duces należeli do kategorii honorowej perfectissimi. Oficjalnie od

1 Ze względów wydawniczych $w$ tekście nie zamieszczono omawianych konstylucji cesarskich w pelnym brzmieniu.

${ }^{2}$ Por. z prac szerzej analizujących status tych oficerów O. Seeck, s.v. Dux, [w:] Paulys Real-Encyclopädie der classischen Altertumwissenschaft, Stuttgart 1894 i n. [cyt. dalej: RE], V, col. 1869-1875; R. G ross e, Römische Militärgeschichte von Galienus bis zum Beginn der byzantinischen Themenverfassung, Berlin 1920, s. 152-180; D. Van B e r ch e m, L'Armée de Dioclétien et la réforme constantinienne, Paris 1952, s. 17 i n.; D. Hof $\mathrm{fmann}$, Das Oberbefehl des spätrömischen Heeres in 4. Jahrhundert n. Chr., [w:] Actes du IXe Congrès international d'études les frontières romaines, Mamaïa, 6-13 septembre 1972, ed. par D. M. Pippidi, Bucarest-Köln-Wien 1974, s. 381-397; J. C. M a n n, Duces and Comites in the 4th Century, [w:] Counsil for British Archeology Research Report 18, The Saxon Shore, ed. D. E. Johnston, London 1977, s. 11-15 = J. C. M a n, Britain and the Roman Empire, London 1996, s. 226-234; R. E. Sm it h, Dux, praepositus, Zeitschrift für Papyrologie und Epigraphik [cyt. dalej: ZPE] 1979, 36, s. 263-278; B. I s a a c, The Meaning of the Terms Limes and Limitanei, Journal of Roman Studies 1988, 78, s. 125-147; A. K a zhd a n, s.v. Doux, [w:] Oxford Dictionary of Byzantium, ed. A. P. Kazhdan, vol. I, New York-Oxford 1991, s. 659; P. S o u the r n, K. R. D i x on, The Late Roman Army, London 1996, s. 58-60; Der Neue Pauly, hrsg. v. H. Cancik und H. Schneider, Stuttgart 1996 in. [cyt dalej: NP], III, col. 852-854.

${ }^{3}$ Obszerną literaturę poświęconą wojskowości późnoantycznej zebrali ostatnio: P. S o u thern, K. R. D ix on, The Late Roman..., passim oraz $\mathrm{P}$. $\mathrm{R} \mathrm{i} \mathrm{ch} \mathrm{a} \mathrm{rdol}$, La fin de l'armée romaine (284-476), Paris 1998, passim. 
386 r. zaliczono ich do grupy senatorskiej clarissimi, a od początku V w. większość duces należała do średniej grupy stanu senatorskiego spectabiles ${ }^{4}$.

Dowódcy w stopniu ducis jako obywatele rzymscy oraz jako żołnierze i urzędnicy wojskowi obdarzeni honorowymi rangami, podlegali ograniczeniom na gruncie prawa prywatnego, w tym prawa małżeńskiego. Conubium, czyli zdolność do zawarcia małżeństwa przysługiwała, według prawa rzymskiego, tylko obywatelom rzymskim. Do czasów Septymiusza Sewera żołnierzy obowiązywał zakaz zawierania małzeństw ${ }^{5}$. Nie dotyczył on jednak oficerów, którzy już we wcześniejszym okresie mogli zawierać iustum matrimonium. Podobnie jak innych urzędników i przedstawicieli warstw wyższych, dowódców w stopniu dux długo obowiązywał zakaz małzeństw z kobietami o niskiej pozycji społecznej. Prawo rzymskie zawsze kwestionowalo dopuszczalność związków małżeńskich osób o nierównym statusie społecznym ${ }^{6}$. W okresie późnoantycznym rozbudowano i uszczegółowiono wspomniane zakazy oraz rozszerzono je na znaczniejszych urzędników oraz duchownych?.

${ }^{4} \mathrm{Na}$ temat statusu senatorów w późnym imperium por. $\mathrm{z}$ nowszej literatury szczegółowej: P. Arsac, La dignité senatoriale au Bas-Empire, Revue historique de droit français et étranger [cyt. dalej: RHDFE] 1969, 47, s. 198-243; A. Chas t a g n o l, L'évolution de l'ordre sénatorial aux IIIe et IVe siècles de notre ère, Revue Historique 1970, 496, s. 305-314; t e $\mathrm{n} \dot{z} \mathrm{e}$, Le Sénat romain à l'époque imperiale. Recherches sur la composition de l'Assemble et le statut de ses membres, Paris 1992; D. S chli $\mathrm{nke} \mathrm{rt}$, Ordo senatorius und nobilitas. Die Konstitution des Senatsadel in der Spätantike. Mit einem Appendix über den praepositus sacri cubiculi, den ,allmächtigen" Eunuchen am Kaiserlichen Hof [Hermes, Einzalschriften 72], Stuttgart 1996 oraz ostatnio P. Heather, [w:] Cambridge Ancient History, t. XIII: The Late Empire, A.D. 337-425, ed. by Av. Cameron, P. Garnsey, Cambridge 1998 [cyt. dalej: CAH], s. 184-210.

${ }^{5}$ Por. np. J. H. Jung, Das Eherecht der römischen soldaten, [w:] Aufstieg und Niedergang der Römischen Welt, Geschichte und Kultur Roms im Spiegel der Neueren Forschung II, [Berlin-New York], 1983, t. XIV, s. 345, oraz uwagi W. Os uchowskieg o, Zarys rzymskiego prawa prywatnego, Warszawa 1962, s. 257-259 z wcześniejszą literaturą przedmiotu i M. K a se ra, Das römische Privatsrecht, t. I, München 1971, s. 71 i n., 312 i n.

${ }^{6}$ Por. regulacje prawne zebrane przez $\mathrm{H}$. Insadowskiego, Rzymskie prawo malzeńskie a chrześcijaństwo, Lublin 1935, s. 200 i n.; G. Kuleczkę, Prawo rzymskie epoki pryncypatu wobec dzieci pozamalzeńskich, Warszawa-Wrociaw-Kraków 1969, s. 49; M. Ka sera, Das römische..., zwłaszcza s. 318 i n.; R. A stolfi e go, La Lex Iulia et Papia, Padova 1986 (2 ed.), s. 98-139; M. Z a błock a, Przemiany prawa osobowego i rodzinnego w ustawodawstwie dynastii julijsko-klaudyjskiej, Warszawa 1987, s. 68 i n.; A. Sokale, Meretrix i jej pozycja w prawie rzymskim, Torun 1998, s. 93-96, z kolejnymi odnośnikami bibliograficznymi.

${ }^{7}$ Szczególne zainteresowanie sprawami rodziny i kwestiami obyczajowymi wykazywał cesarz Konstantyn I Wielki. W jego działalności ustawodawczej ponad jedna czwarta konstytucji poświęcona była rodzinie i kwestiom obyczajowym. Zachowało siẹ ponad 380 konstytucji lub ich fragmentów (przypisywanych jest mu niekiedy dalszych 276 fragmentów). Por. J. E. Grubbs, Constantine and Imperial Legislation on the Family, [w:] The Theodosian Code. Studies in the Imperial Law of Late Antiquity, ed. by J. Harries and I. Wood, London 1993, s. 120-142. Autorka ta zagadnieniu temu poświęciła opublikowaną później monografię pt. Law and Family in Late Antiquity. The emperor Constantine's legislation on marriage, Oxford 1995. 
2.1. Zakaz małżeństw $z$ kobietami o niskiej pozycji społecznej w okresie późnoantycznym ujęty został $w$ dwóch aktach normatywnych: konstytucji Konstantyna I Wielkiego z $336 \mathrm{r}$. i noweli Marcjana z 454 r., adresowanych do ówczesnych prefektów pretorianów ${ }^{8}$. Fakt, iż obydwa akty skierowane były do urzẹdnika cywilnego, jakim stał się $w$ późnym antyku prefekt pretorianów, nie oznacza, iż nie dotyczyły one wojskowych' ${ }^{9}$ W późnym cesarstwie rzymskim nie zawsze bylo przestrzegane - wprowadzone na przełomie III i IV w. - rozróżnienie kompetencji między pionem administracji cywilnej i wojskowej. Ponadto wyżsi wojskowi, w tym i duces, awansowali szybko do warstwy senatorów ${ }^{10}$. Najpóźniej od tego momentu konstytucje dotyczące senatorów - a do takich należaly omawiane akty prawne - miały wobec nich zastosowanie.

Konstantyn I zakazał uznawania dzieci pochodzących $z$ małżeństw $\mathrm{z}$ kobietami z określonych grup społecznych - senatorom, perfectissimi (do tej honorowej kategorii należeli duces do drugiej połowy IV w.), wyższym urzędnikom miejskim oraz flaminom i kapłanom prowincjonalnym. Kobiety, o których konstytucja wspominała, to: niewolnice, córki niewolnic, byłe niewolnice lub ich córki, aktorki lub ich córki, kobiety prowadzące gospody

${ }^{8}$ Theodosiani libri XVI cum Constitutionibus Sirmondianis, IV, 6, 3, edidit adsumpto apparatu P. Kruegers, Th. Mommsen, Berolini 1954, t. I; przekład: The Theodosian Code and Novels and the Sirmondian Constitution, a translation with commentary, glossary and bibliography by C. Pharr with an introduction by C. Dickermann Williams, Princeton 1952 [cyt. dalej: CTh] $=$ Codex Justinianus V, 27, 1 (ze zmianami), ed. Corpus Iuris Civilis, t. II, recongnovit et retractavit P. Krueger, Berlin 1954 [cyt. dalej: C]; Novela Marciani 4 (ed. CTh, t. II) $=\mathrm{C} \mathrm{I}, 14,9 ; \mathrm{C} \mathrm{V}, 5,7$ (ze zmianami). Na temat tych regulacji por. B. B i ond i, Il diritto romano christiano, t. III, Milano 1954, s. 86; M. K a s e r, Das römische..., t. II, s. 165; R. Astolfi, La Lex Iulia.., s. 130 i n., A. Sokala, Meretrix i jej..., s. 97-99, z dalszą literaturą.

${ }^{9}$ Kompetencje wojskowe prefekt utracil za Konstantyna Wielkiego (306-337). Por. na temat prefekta pretorianów w póżnym antyku: J,-R. Palanque, Les préfets du prétoire de Constantin, [w:] Mélanges H. Grégoire..., Bruxelles 1959, II, s. 483-491; W. En Bli n, s.v. Praefectus praetorio, [w:] RE XXII, 2, col. 2391-2502 (okres póżnoantyczny col. 2462-2502).

${ }^{10}$ Por. G. A $1 \mathrm{f} \not ̈ l \mathrm{~d}$ y (Historia spoleczna starożytnego Rzymu, thum. A. Gierlińska, Poznań 1998, s. 253): To nie oni [tj. senatorowie, J. W.] wchodzili do grona 'viri militares', lecz ci ostatni otrzymywali godność senatorska. Pomimo wykluczenia $\mathrm{z}$ grona senatu spectabiles i clarissimi $\mathrm{w}$ drugiej połowie $\mathrm{V}$ w., osoby noszące te tytuły traktowano jako należące do niższej grupy senatorów. Por. Iustiniani Digesta I, 9, 12 (ed. Corpus Iuris Civilis, t. I, recognovit Th. Mommsen, retractavit P. Krueger [cyt. dalej: D.]; C: XII, 3, 3 (wydana za cesarza Zenona); III, 24, 3 (z lat 485-486?) i późniejsza zmiana za Justyniana Wielkiego: Novella Iustiniani 62 c. 2,5 z 537 r. (ed. Corpus Iuris Civilis, i. III, recognovit R. Schoell, Berlin 1954) [cyt. dalej: Nov. Iust.]. Por. R. G u ill a nd, Egrege-perfectissime-clarissime, [w:] Epétèris Etaireias Buzantinon Spoudon 1967, 35, s. 17-40, zwłaszcza s. $32=$ R. G u illand, Titres et fonctions de l'Empire byzantin, London 1976, I; A. H. M. J on es, The Later Roman Empire (284-602). A Social, Economic and Administrative Survey, vol. II, Oxford-Cambridge Mass. 1964, s. 529; A. Lippold, s.v. Zenon 17 Kaiser, [w:] RE X, col. 209-210. 
oraz córki mężczyzn prowadzących gospody, kobiety poniżone - zdegradowane (humili) lub niskiego pochodzenia ${ }^{11}$, córki stręczycieli ${ }^{12}$, zapaśników (gladiatorów) oraz sprzedawczynie prowadzące dozwolony handel.

Według omawianej regulacji, uznanie dziecka pochodzącego ze związku $\mathrm{z}$ taką kobietą za prawowite groziło uznającemu infamią ${ }^{13}$, a także uznaniem za cudzoziemca, czyli pozbawieniem obywatelstwa rzymskiego ${ }^{14}$. Regulacja ta wskazywała, że jeżeli ojciec należący do wymienionych grup uprzywilejowanych darowal coś dzieciom ze związków z kobietami „niegodnymi” lub im samym, to dobra te winny być im odebrane i zwrócone uprawnionym dziedzicom. Konstytucja dotyczyła zarówno sytuacji, gdy ojciec ofiarował coś osobiście lub darowizna została uczyniona $w$ jego imieniu, ale również w wypadku, gdy dobra zostały kupione w imieniu matki lub dziecka. W przypadku braku dziedziców lub niepodjęcia przez nich działań, w celu uzyskania należnego im majątku $w$ terminie dwóch miesięcy nakazywano przejęcie tych dóbr na rzecz fiskusa. W postępowaniu mającym na celu odzyskanie dóbr zezwalano na stosowanie tortur wobec kobiet obdarowanych ${ }^{15}$. Poza tym w procedurze o przejęcie dóbr przez fiskusa dopuszczano stosowanie tortur wobec osób obdarowanych, a wobec opornych przewidziano również karę grzywny quadruplum, obliczaną stosownie do wartości ofiarowanego im majątku.

$"$ Po analizie poglądów prezentowanych w literaturze A. Sok a la (Meretrix $i$ jej..., s. 97-98) proponuje do kategorii tej zaliczyć też prostytutkę.

$12 \mathrm{Na}$ temat przyczyn nieumieszczenia osobnego zapisu na temat stręczycielki por. A. S ok a la, Lenocinium w prawie rzymskim, Toruń 1992, s. 34-35, z odnośnikami do wcześniejszej literatury.

${ }^{13}$ Infamia była karą polegającą na całkowitej utracie praw obywatelskich lub umniejszeniu niektórych praw publicznych. Była karą samoistną oraz karą dodatkową dla sprawców niektórych delikiów. W okresie chrześcijańskim orzekano ją wobec sprawców przestępstw religijnych. Infamię powodowało też wykonywanie zawodów hańbiących, bankructwo, niehonorowe zwolnienie $z$ wojska oraz cały szereg innych niegodnych zachowań. $\mathrm{Na}$ temat infamii w okresie poklasycznym por. Th. Mommsen, Römisches Strafrecht, Leipzig 1899, s. 993-998 i poszczególne jej rodzaje sachregister s. 1057; P fa ff, s.v. Infamia, [w:] RE IX, col. 1537-1540; M. K u r y łowi cz, Prawo i obyczaje w starożytnym Rzymie, Lublin 1984, s. 197-200; J. Ka miński, W. R ozwadowski, s.v. Infamia, [w:] Prawo rzymskie. Slownik encyklopedyczny, red. W. Wołodkiewicz, Warszawa 1986, s. 73; W. Lit e w sk i, s.v. Infamia, [w:] t e nże, Slownik encyklopedyczny prawa rzymskiego, Kraków 1998, s. 118.

is Czyli jako peregrini dedictii, gdyż peregrini certae civitatis otrzymali obywatelstwo rzymskie na podstawie Constitutio Antoniniana z 212 r. Por. D. I, 5, 17. Interpretacja edyktu, a zwłaszcza jego zakresu podmiotowego wywołuje spory; por. A. H. M. Jones, Studies in Roman Government and Law, Oxford 1960, Ch. VIII; te nże, The Later..., s. 16-18; W. Osuch owski, Constitutio Antoniniana, Roczniki Teologiczne-Kanoniczne 1963, T. X, z. 4, s. 65-82. Kategoria peregrini dedictii została zlikwidowana dopiero przez Justyniana I w 530 r. - C VII, 5, 1; I. I 5, 3.

${ }^{15}$ Por. ogólnie na temat tortur w prawie rzymskim Th. Mommsen, Römisches..., s. 401-420; A. Erhardt, s.v. Tormenta, [w:] RE VI A, col. 1775-1794; E. Pe te rs, Torture, Philadelphia 1996 , s. $18-33$. 
Treść konstytucji z 336 r. wywoływała wątpliwości i została wyjaśniona w noweli z 454 r. $^{16}$ Przedmiotem sporów było to, czy dopuszczalne są związki senatorów z kobietami wolno urodzonymi, lecz ubogimi. Według prezentowanego $w$ noweli stanowiska, już $w$ omówionej regulacji Konstantyn I zakazał malżeństw między wymienionymi w niej „niegodnymi” kobietami i mężczyznami należącymi do wskazanych grup spolecznych ${ }^{17}$. Zgodnie z przyjętą przez Marcjana mniej rygorystyczną interpretacją treści konstytucji Konstantyna I, dozwolone były małzeństwa senatorów oraz innych osób obdarzonych najwyższymi godnościami z kobietami wolno urodzonymi, chociaż ubogimi. Kobiet takich nie uznawano za "niegodne”. Według noweli, nie było różnicy między biednymi kobietami wolno urodzonymi a innymi wolno urodzonymi ${ }^{18}$. Wymieniono $\mathrm{w}$ niej ponownie listę kobiet uznawanych za "niegodne” (analogiczną do zawartej w konstytucji Konstantyna I), lecz zakaz małżeństw z nimi ograniczono tylko do senatorów. Tym samym zawężono zakres podmiotowy tej regulacji $\mathrm{i}$ złagodzono jej surowość.

Przesłanką do wprowadzenia omówionych regulacji była ochrona interesów majątkowych rodzin warstw uprzywilejowanych ${ }^{19}$. Ich ratio legis była również ochrona autorytetu panującego i państwa, gdyż dotyczyly one dignitatibus praediti $^{20}$. W noweli Marcjana pojawiło się sformułowanie zakazu zbliżone do pojęcia impedimentum matrimonii, czyli okoliczności, które nie pozwalały

${ }_{16}$ We wstępie do noweli wskazano, że prawa obowiązujące wszystkich winne byc powszechnie zrozumiałe i że cesarz winien wątpliwości objaśnić przez interpretacją prawa. W tekście przejętym w C I, 14, 9 wskazano dodatkowo, że surowe prawo winno być lagodzone. Nowela z 454 r. potwierdzała też ważność innych konstytucji Konstantyna I w sprawach małżeńskich i rodzinnych.

${ }^{17}$ Wobec wymienionych w niej kategorii kobiet ,niegodnych" Konstantyn I użył dwukrotnie terminu „uxor". R. A stolfi ( La Lex Iulia..., s. 130), powołując się na to, iż dzieci pochodzące $z$ takich związków uznawano za nieważne, zasadnie dowodzil, że wedhug CTh IV, 6, 3: Il matrimonio continua a essere nullo: Constantino precisa che i figli nati da queste unioni sono illegitimi. Odwołał się także do konstytucji Justyna I i Justyniana I znoszących ograniczenia swobody zawierania małżeństw (por. niżej). Stanowisko tego autora należy uznać za słuszne. Wydaje się zatem, że występujący w tekście CTh IV , 6, 3 termin „uxor" był użyty przez ustawodawcę w znaczeniu szerszym niż „żona”. Oznaczał on kobietę pozostającą w trwałym związku, który jednak - według Konstantyna I - nie był iustum matrimonium.

${ }^{18}$ Novella Marciani 4, 2 in fine: Sed licere statuimus senatoribus et quicumquae amplissimis dignitatibus praeditis ex ingenuis natas, quamvis pauperes, in matrimonium sibi adscire nullamquae inter ingenuas ex divitiis et opulentiore fortuna esse distantiam. Według interpretatio do tej noweli, taka praktyka dozwolona jest w stosunku do wszystkich: Quod et omnibus exemplo legis huius sine dubitatione permittur.

19 Por. B. Biondi, Il diritlo..., s. 85-86; J. A. R. Korsunski, 'Honestiores' i 'Humiliores' $\checkmark$ zakonodatelnych pamiatnikach Rimskoj Imperii, Vestnik Drevnej Istorii 1950, I, zwłaszcza s. 86-87; J. E. Grubbs, Constantine..., passim.

${ }^{20}$ Por. Novella Marciani 4, 2. 
zawrzeć ważnego małżeństwa. Fakt, iż obydwa akty prawne przejęte zostały do Kodeksu Justyniańskiego, rodzi wątpliwość co do ich obowiązywania. Analiza fragmentów włączonych $w$ ten sposób do tego zbioru prowadzi do wniosku, iż w okresie sporządzania drugiej redakcji Kodeksu Justyniana (lata 533-534), uznawano za ważne małżeństwa perfectissimi, wyższych urzędników miejskich (duumviri lub duoviri) oraz niektórych kapłanów prowincjonalnych ${ }^{21} \mathrm{z}$ kobietami „niegodnymi",22. Zakazywano natomiast takich małżeństw senatorom, $\mathrm{z}$ wyjątkiem związków z kobietami wolno urodzonymi, lecz ubogimi. Skuteczne były równiez ujęte w konstytucji Konstantyna I zakazy dyspozycji majątkowych na rzecz kobiet „niegodnych” i zrodzonego w związkach $\mathrm{z}$ nimi potomstwa ze strony senatorów, perfectissimi, duoviri i niektórych kapłanów. Utrzymano również $w$ mocy procedury mające na celu odzyskanie majątku przez prawowitych spadkobierców lub przejęcie go przez fiskusa.

2.2. Zakazy przewidziane $w$ konstytucji Konstantyna I i noweli Marcjana byly znoszone stopniowo $\mathrm{w}$ pierwszej połowie VI w.

Zakaz zawierania małżeństw $\mathrm{z}$ aktorkami zmodyfikowany zostal przez cesarza Justyna $I \mathrm{w}$ edykcie datowanym na lata 520-524.23. Zrównano $\mathrm{w}$ nim status wyzwoleńców $\mathrm{z}$ wolno urodzonymi oraz sytuacje byłych aktorek, a także córek aktorek $\mathrm{z}$ kobietami wolno urodzonymi. Zezwolono im $\mathrm{m}$. in. zawierać małżeństwa $\mathrm{z}$ mężczyznami zajmującymi najwyższe stanowiska państwowe, pod warunkiem uzyskania zezwolenia cesarskiego ${ }^{24}$. Wydanie tej konstytucji było podyktowane potrzebą zalegalizowania związku cesarskiego siostrzeńca, przyszłego cesarza Justyniana I, $z$ jego ukochaną - Teodorą ${ }^{25}$. Była ona córką tresera i byłej aktorki, a jej barwne przedmałzeńskie życie znane jest $\mathrm{z}$ fragmentu pamfletu Pro-

${ }^{21} \mathrm{~W}$ tekstach konstytucji i noweli użyto ogólnego terminu „sacerdotes”, który w czasach chrześcijańskich oznaczal prezbitera; por. np. A. Berger, Encyclopedic Dictionary of Roman Law, Philadelphia 1953, s. 687. W tekście przejętym w Kodeksie Justyniańskim pominięto osoby obdarzone godnością quinquennalius i pogańskich flaminów oraz wskazano, iż zakaz dotyczył kapłanów Phoenicarchiae vel Syriarchiae.

${ }^{22} \mathrm{Z}$ wyjątkiem byłych aktorek i wyzwolenic, którym status już wcześniej zrównano z osobami wolno urodzonymi; por. niżej.

${ }^{23} \mathrm{C} \mathrm{V}, 4,23$.

${ }^{24}$ Por. R. Astolfi, La Lex Iulia..., s. 130-131.

${ }^{25}$ Pomimo że cesarz powoływał się na przyrodzoną równość wszystkich ludzi; por. B. B i on di, Il diritto..., t. III, s. 86. Por. też Assunta Nagl, s.v. Theodora, [w:] RE V A, col. 1776-1791; B. R u bi in, Prokopios von Kaisareia, Stuttgart 1954 = RE XXIII, 1, col. 273-599; te nż e, Das Zeitalter Justinians, Bd. 1, Berlin 1960, s. 98-121, zwłaszcza s. 107; M. K a s e r, Das römische..., t. II, s. 165 p. 28 wraz z cytowaną dalszą literaturą; H. G. B e ck, Kaiserin Theodora und Prokop. Der Historiker und seine Opfer, München 1986; R. B r own ing, Justynian i Teodora, tłum. M. Boduszyńska-Borowikowa, Warszawa 1996, s. 51-56. 
kopiusza $\mathrm{z}$ Cezarei pt. Historia sekretna ${ }^{26}$. Dzięki temu edyktowi stało się możliwe malżeństwo Justyniana $\mathrm{z}$ Teodorą, zawarte $\mathrm{w} 525 \mathrm{r}^{27}$ Pozostake ograniczenia wymienione $w$ analizowanych konstytucjach Konstantyna oraz Marcjana zniesione zostały w późniejszym ustawodawstwie justyniańs$\mathrm{kim}^{28}$. Proces likwidacji ograniczeń w swobodzie zawierania małżeństw ze względu na przesłanki etyczne i socjalne dokonał się pod wpływem chrześcijaństwa ${ }^{29}$.

${ }^{26}$ Procopii Caesariensis, Historia quae dicitur Arcana, 9. (edycja: J. Haury, Procopii Ca es a rie ns i s, Opera Omnia, t. III, Lipsiae 1964; polska wersja jezykowa: P r o k o pi u s z z Ce zare i, Historia sekretna, thum. A. Konarek, Warszawa 1977).

${ }^{27}$ Według Prokopiusza (Historia quae..., 6), rządy Justyna I były czysto tytularne i decyzje państwowe podejmowal Justynian Wielki. Por. też A. A. Vasili ev, Justin the First. An Introduction to the Epoch of Justinian the Great, Cambridge Mass. 1950, s. 163; G. Ost rog orski, Dzieje Bizancjum, thum. pod red. H. Evert-Kappesowej, Warszawa 1967, s. 81. Odmiennie B. R ubin, Das Zeitalter..., t. 1, s. 67-68. Przyrównał on stosunki między Justynem I a Justynianem do współpracy wodza i adiutanta. Wskazał, że Justyn, nie mający wyczucia w sprawach cywilnego zarządu państwem wyręczał się w tym względzie Justynianem. Sobie pozostawil natomiast stosunki $\mathrm{z}$ armią. Biorąc pod uwage te stanowiska, należy przyjąć, iż promotorem wydania omówionego edyktu był sam Justynian, być może pod wpływem Teodory. Na temat wpływu Teodory na prawodawstwo tego okresu, a w tym w kwestiach małżeńskich por. też J. E. Spru it, L'influence de Theodora sur la Legislation de Justinien, Revue Internationale des Droits de l'Antiqué [cyt. dalej: RIDA] 1977, no 24, s. $389-421$

${ }^{28}$ C: 14,33 i V 4, 28 z 534 r. (pierwsza zezwalająca na małzeństwa $z$ wyzwolenicami i córkami aktorek; druga zakazująca rozwiązywania wcześniejszych malżeństw z wyzwolenicą lub wyzwoleńcem, w przypadku osiągnięcia przez małżonka lub teścia wyzwoleńca godności senatorskiej; znosiły one również wymóg uzyskania zezwolenia cesarskiego na zawarcie malżeństwa); Nov. Iust.: 78, 3 z 539 r. (dopuszczalne malżeństwo z wyzwolenica) i 117, 6 z 542 r. (inne ograniczenia wynikające z konstytucji Konstantyna i noweli Marcjana, o których to regulacjach nowela ta wprost wspomina). Por. H. In sadowski, Rzymskie prawo..., s. 203; B. Bi ond i, Il diritto..., s. 86; M. K a se r, Das römische..., t. II, s. 165; R. A st olfi, La Lex Iulia..., s. 131-133. Likwidacji zakazów małżeńskich w ustawodawstwie justyniańskim nie dostrzegł jak się zdaje A. Sokala, Meretrix i jej..., s. 98-99.

${ }^{29} \mathrm{Na}$ temat relacji między prawem rzymskim a pojęciami chrześcijańskimi, w tym $\mathrm{w}$ kwestiach małżeńskich, istnieje ogromna literatura przedmiotu; por. zestawienie S. L ong os $z$ a [w:] Vox Patrum 1985, z. 8-9, s. 449-507, a zwłaszcza s. 507-509. Podstawowym studium w piśmiennictwie polskim pozostaje praca H. I nsadowskiego, Rzymskie prawo... Ostatnio na ten temat pisał J. Iluk, Malzeństwo $w$ okowach prawa i Kościola. $Z$ dziejów późnorzymskiego spoleczeństwa, Przegląd Religioznawczy 1994, nr 172, z. 2, s. 3-29; t e n że, Rodzina i wspólnota w starożytnym chrześcijaństwie, [w:] Rodzina $w$ spoleczeństwach antycznych i wczesnym chrześcijaństwie. Literatura, Prawo, Epigrafika, Sztuka, red. J. Jundzilł, Bydgoszcz 1995, s. 215-240; te nż e, Chrześcijańskie malżenstwo $i$ rodzina $w$ rzymskiej starożytności, [w:] W. Pałubicki, J. I luk, Malżeństwo i rodzina $w$ dawnym judaizmie $i$ starożytnym chrześcijaństwie, Gdańsk 1995, s. 153-287, a zwłaszcza s. 223-245, 265-266 (tamże bibliografia innych prac polskojęzycznych). Na temat wpływu pojęć chrześcijańskich na prawo małżenskie por. też B. B io nd $\mathrm{i}$, Il diritto..., s. 69-102; M. Ka ser, Das römische..., t. II, s. 158 z. dalszą literaturą. 
2.3. Źródla nie dostarczają przykładów związków dowódców wojskowych w stopniu dux z kobietami "niegodnymi" 30 . Duces karierę zaczynali często jako prości żołnierze i po kilkudziesięciu latach służby osiągali wyższe stopnie oficerskie ${ }^{3 !}$. Armia była jedną $z$ głównych dróg awansu społecznego w społeczeństwie późnorzymskim, które pomimo hierarchicznego charakteru nie było społeczeństwem ,kastowym”32. Nigdy nie doszło w późnym cesarstwie do wyodrębnienia grupy rodzin, spośród której wywodzili się wyżsi dowódcy wojskowi, i zamknięcia tym samym drogi awansu dla niższych oficerów i prostych żołnierzy. Poszczególne przypadki awansów członków tej samej rodziny nie mogą być dowodem na kształtowanie się systemu doboru kadr imperialnej armii, opartego na przekonaniu o przymiotach wynikających z ,dobrego" urodzenia. W okresie późnego cesarstwa rzymskiego przy awansach oficerskich uwzględniano - tak, jak w okresie pryncypatu - głównie osobiste kwalifikacje i cechy charakteru danego kandydata ${ }^{33}$. W spoleczeństwie późnorzymskim - w odróżnieniu od okresu wczesnego cesarstwa - prestiż wiązał się głównie $z$ posiadaniem władzy i pieniędzy, a nie z pochodzeniem ${ }^{34}$.

${ }^{30}$ Por. źródła zestawione w pracach powolanych w przyp. 2 oraz biogramy znanych ducis [w:] Prosopography of the Later Roman Empire, vol. I, ed. A. H. M. Jones, J. R. Martindale, J. Morris, Cambridge 1971; vol. II, ed. J. R. Martindale, Cambridge 1980; vol. III, ed. J. R. Martindale, Cambridge 1992; RE; NP oraz dla dowódców w tym stopniu z obszaru dolnodunajskiego: J. Wiewiorowski, Moesiae Secundae et Scythiae Minoris exempla prosopographica, [w:] Scripta Minora III, red. B. Lapis, Poznań 1999, s. 361-363, 365-366, 375-376, 393-398, 408, 410-413, 418-419, 426-427, 434-436, 437-439, 445-447, 451, 452.

${ }^{31}$ Wskazuje na to przykład kariery Flawiusza Abinnaeusa, której szczegóły znane są z jego archiwum papirusowego (The Abinnaeus Archive. The Papers of a Roman Officer in the reign of Constantius II, collected and reedited by H. I. Bell, V. Martin, E. G. Turner, D. Van Berchem, Oxford 1962). Po 40 latach słuzby doszedł on do stosunkowo niskiego stanowiska - dowódcy garnizonu w mieście Dionysiopolis w Egipcie. Odosobnionym przykładem jest kariera przyszłego cesarza Teodozjusza I, który w wieku 28 lat objałł urząd ducis prowincji Moesiae primae (lata 373-374 r.). Por. Ammianus Marcellinus, Res Gestae, XXIX 6, 5 (ed.: Römische Geschichte, Lateinisch und Deutsch und mit einem Kommentar, ed. W. Seyfarth, T. 1-4, Berlin 1978; ed. angielska J. C. Rolfe, Loeb Classical Library, vol. I-III, London-Cambridge 1958-1963).

${ }^{32}$ A. H. M. Jones, The Caste System in the Later Roman Empire, Eirene 1970, no 8, s. 79-96; W. Cera n, Stagnation and Fluctuation in Early Byzantine Society, Byzantinoslavica 1970, 31, s. 192-203 oraz ostatnio A. M arcone, [w:] CAH, 1. XIII, s. 363-366 i 369-370.

${ }^{33}$ Tezę o kształtowaniu sị arystokracji wojskowej w okresie późnorzymskim wysunął A. De mandt, Der Spätrömische Militäradel, Chiron 1980, 10, s. 609-637, a zwłaszeza s. 626. Odmiennie, odrzucając tę koncepcje, E. P. Gluschanin w obszernym studium pt. Der Militäradel des frühen Byzanz, Scripta Classica, Medievalia et Archeologica Sibiraca 1, Barnaul-Dień 1991. Stanowisko jego należy uznać za słuszne.

${ }^{34}$ Trafnie określił to zjawisko J. B. Bury (A History of the Later Roman Empire from the Death of Theodosius to the Death of Justinian, vol. I, London 1923 (reed. New York 1958), s. 40): The Imperial army was democratic in the sense that the humblest soldier, whatever his birth might be, might attain to the highest commands be sheer talent and capacity. Por. też G. Alföldy, Historia spoleczna..., s. 248; P. Veyne [w:] Historia życia prywainego, 
Łatwiejszą karierę $w$ wojsku mieli zapewnioną lepiej urodzeni czy synowie oficerów, a także osoby awansowane ${ }^{35}$ dzięki protekcji lub wręczonym lapówkom. Służba wojskowa przyczyniała się do tego, że przedstawiciele nawet najniższych warstw osiągnąc mogli najwyższe stanowiska w państwie, nie wyłączając godności senatorskich i tronu cesarskiego ${ }^{36}$.

Wywodząc się spośród prostych żołnierzy, duces mogli zapewne pozostawać w trwałych związkach z kobietami „niegodnymi" ${ }^{37}$. W przypadku powtórnego małżeństwa (jako wyżsi oficerowie) - aż do czasów justyniańskich - musieli oni przestrzegać zakazów małżeństw określonych w konstytucjach Konstantyna I, noweli Marcjana, jak i wcześniejszym prawodawstwie rzymskim zakazującym małżeństw mieszanych między przedstawicielami warstw uprzywilejowanych i osobami niewłaściwego pochodzenia lub profesji. Związki takie musiały być $w$ praktyce stosunkowo rzadkie. Wśród rzymskiej arystokracji senatorskiej i urzędniczej, w tym wśród wojskowych powszechna była bowiem tendencja do zawierania małżeństw we własnym kręgu ${ }^{38}$.

t. I: Od Cesarstwa Rzymskiego do roku tysiecznego, red. P. Veyne, thum. K. Abramowicz, M. Roztworowska, Wrocław-Warszawa-Kraków 1998, s. 127.

${ }^{35}$ Określa się ją jako system suffragium. Oznaczał on udzielanie rekomendacji, a następnie uzyskanie urzędowego aktu mianowania $\mathrm{i}$ wpisu na listę urzędników, w zamian za uiszczenie oplaty (sportula). Por. m. in. G. Kolias, Ämter- und Wördenkauf im früh- und mittelbyzantinischen Reich, Athen 1939; J. K a r a y a n o pulos, Das Finanzwesen des frühbyzantinischen Staates, München 1958, s. 168-177; C. Collol, La pratique et l'institution du 'suffragium' au Bas-Empire, RHDFE 1965, 43, s. 185-221; R. M a cM ulle n, Corruption and Decline of Rome, New Heaven and London 1988, s. 150-152, 162-168. Zjawisko to spotykało się $z$ próbami przeciwdziałania ze strony panujących, którzy zwłaszcza $w$ armii niechętnie postrzegali awans osób przypadkowych. Uiszczanie opłat w zamian za mianowanie na stanowisko prowadziło bowiem w praktyce do kupowania urzędów. Nieformalne opłaty stały się jednak $z$ czasem powszechne i suffragium zostało $w$ części zaakceptowane $w$ ustawodawstwie cesarskim. Za panowania cesarza Zenona, a ostatecznie za Justyniana Wielkiego opłaty te stały się dodatkowym źródłem dochodów dla skarbca cesarskiego jako podatek. Por. C I, 27, 1, 19 i C I, 27, 2, 35 (z 534 r. wobec dowódców w stopniu dux prefektury Afryki); Nov. Iust: 8 c. 2,3 i 5; 24-27 in fine (wszystkie z 535 r.); 30 c. 6 (z 536 r.); Edictum Iustiniani 4 c. I (ed. Nov. Iust.)

${ }^{36}$ Skrótowo zagadnienie to podsumowal już M. R ostovtzeff (The Social an Economic History of the Roman Empire, Oxford 1926, s. 459): Naturally the families of higher officers became in cource of time the main source of supply of officers in general, and thus a new military aristocracy was formed, which however, never became a closed caste. Por. przypadek kariery cesarza Justyna - od prostego, niepiśmiennego żołnierza do purpury cesarskiej. Na jego temat por, monograficzne studium A. A. Vasilieva: Justin the First... Por. tez A. H. M. Jones, The Later..., s. 550; A. A. Cekalova, Senatorskaja aristokracija Konstantinopolia v piervoj polovinie VI v., Vizantijskij Vremennik 1972, 33, s. 22.

${ }^{37}$ Por. C V, 4, 28 z 534 r., z której wynika, że w okresie przed jej wydaniem małżeństwa takie były rozwiązywane.

${ }^{38}$ Por. M. T. W. A rn heim, The Senatorial Aristocracy in the Later Roman Empire, Oxford 1972, s. 103-142; A. Demandt, Der Spätrömische Militäradel..., passim; te nże, The 
3.1. W okresie późnoantycznym wprowadzono zakazy małżeńskie obowiązujące chrześcijan. Po ogloszeniu przez Teodozjusza I w $381 \mathrm{r}$. aktu supremacji religii chrześcijańskiej ${ }^{39}$, powszechne bylo przekonanie, że Kościól i państwo stanowiq jedna i te samq spolecznossć ludzkq ,imperium Romanum's(). Stąd formalnie jedynym uznawanym wyznaniem był katolicyzm. Mimo prześladowań i zakazów sprawowania funkcji publicznych przez niekatolików ${ }^{41}$, w IV i V w. poganie często pełnili nawet najwyższe funkcje państwowe ${ }^{42}$. Tolerowany był też kult ariański u germańskich najemników tego wyznania ${ }^{43}$. Pomimo powyższych zastrzeżeń uznać należy, że zakazy małżeńskie obowiązujące chrześcijan de iure miały $w$ prawie rzymskim charakter powszechnie obowiązujący.

W doktrynie chrześcijańskiej, po edykcie tolerancyjnym z 313 r., szybko pojawiło się zagadnienie dopuszczalności małżeństw między chrześcijanami i poganami lub Żydami oraz katolikami i heretykami ${ }^{44}$. Przestrzeganie zasad moralności chrześcijańskiej dhugo jednak było kwestią obyczaju, a nie obowiązującego prawa ${ }^{45}$.

Osmosis of Late Roman and Germanic Aristocracies, [w:] Das Reich und die Barbaren, hrsg. v. E. K. Chrysos, A. Schwarcz, Wien-Köln 1989, s. 75-86.

${ }^{39} \mathrm{CTh} \mathrm{XVI}, 1,2$. Na ten temat por. ostatnio K. Il ski, Religijna przeslanka jedności państwa $w$ 'De fide catholica' (CTh XVI, 1, 2) i jej kontekst historyczny, [w:] Scripta Minora III, red. B. Lapis, s. $463-479$.

${ }^{40}$ Cytal pochodzi z pracy C. Barınika, Chrześcijanie pierwszych wieków wobec życia publicznego. Problem teologiczny, [w:] Chrześcijanie a życie publiczne, red. J. Śrutwa, Lublin 1988 , s. 22.

41 Por. szczególowa charakterystyka regulacji przeciwko apostatom, heretykom i poganom dokonana przez A. Dę bińsk ie go, Ustawodawsiwo karne rzymskich cesarzy chrześcijanskich w sprawach religijnych, Lublin 1990, s. 66-69, 71-113, 132-144, 150-174; t e n ż e, Ustawodawstwo chrześcijańskich cesarzy rzymskich przeciw Manichejczykom, Kościół i Prawo 1992, 8, s. 195-211. Patrz też z wcześniejszej literatury B. B i on di, Il diritto..., t. 1 (Milano 1952), s. 253-357; K. L. Noethlichs, Die gesetzgeberischen Maßnahmen der christlichen Kaiser des vierten Jahrhunderts gegen Häretiker, Heiden und Juden, Köln 1971; F. T in n efeld, Die Frühbyzantinische Gesellschaft. Structur Gegensätze Spannungen, München 1977, s. 271-282. Szczególne znaczenie dla ugruntowania zakazów sprawowania funkcji publicznych przez niekatolików miało ustawodawstwo Teodozjusza II; por. np. W. K. B o yd, The Ecclesiastical Edicts of the Theodosian Code, London 1905; O. Martin, Theodosius Laws on heretics, American Annual Ecclesiastical Review 1950, 123, s. 117-136; C. L u bhe id, Theodosius II and heresy, The Journal of Ecclesiastical History 1965, 16, s. 13-38.

${ }^{42}$ Por. np. ustalenia zawarte w studium $\mathrm{R}$. von $\mathrm{H}$ a e hling a, Die Religionszungehörigkeit der hohen Amtstränger des römischen Reiches seit Constantinus I Alleinherrschaft bis zum Ende der Theodosianischen Dynastie (324-450 bzw. 455 n. Chr.), Bonn 1978, z wcześniejszą literaturą.

${ }^{43}$ Ustawowe potwierdzenie tej tradycji nastąpiło dopiero za rządów Justyna 1 i Justyniana I: C I, 5, $12 \S 17$.

${ }^{4}$ Por. przykłady ówczesnych zapatrywań wśród chrześcijan: M. S i mon, Cywilizacja wczesnego chrześcijaństwa, tłum. E. Bąkowska, Warszawa 1979, s. 157-158; J. 11 u k, Chrześcijańskie malzenstwo..., s. 232 i $\mathrm{n}$.

45 Jak pisal św. Hieronim w Liście LXXVII, 3 z 399 r. (wyd. Listy, thum. J. Czuj, t. 2, Warszawa 1953), inne są (malżeńskie) prawa Cezarów, inne Chrystusa. Co innego nakazuje Papinianus, co innego nasz Pawel. 
3.2. Po 388 r. w prawie rzymskim zakazane zostały związki małżeńskie między chrześcijanami a Żydami ${ }^{46}$, zgodnie $z$ poglądami rozpowszechnionymi wówczas wśród chrześcijan i z rzymskim ustawodawstwem antyżydowskim ${ }^{47}$.

Podstawowym celem tego ustawodawstwa było przeciwdziałanie żydowskiemu prozelityzmowi ${ }^{48}$. Przynależność jednego $z$ nupturientów do gminy żydowskiej byla zatem okolicznością, która nie pozwalala zawrzeć ważnego małżeństwa. Związek małżeński z Żydem był równoznaczny z dopuszczeniem się cudzolóstwa (adulterium) ${ }^{49}$. Różne sposoby karania za adulterium znane są z Digestów Justyniańskich ${ }^{50}$. Od III w. za tę zbrodnię wymierzano najczęściej kare śmiercis ${ }^{51}$, praktykę tẹ kontynuowali cesarze chrześcijańscy, uznając adulterium za świętokradztwo (sacrilegium) ${ }^{52}$. Sprawca adulterium nie mógł liczyć na laskę panującego i darowanie kary ${ }^{53}$.

3.3. Przynależność duces do warstwy uprzywilejowanej (honestiores) oznaczała w prawie karnym zakaz stosowania wobec nich kwalifikowanej kary śmierci ${ }^{54}$.

$\overline{{ }^{46} \mathrm{CTh} \text { III, 7, }} 2=\mathrm{CTh}$ IX, 7, $5=\mathrm{C} \mathrm{I}, 9,6$. Jej adresatem byl prefekt pretorianów. Pomimo to, analogicznie jak w przypadku konstytucji CTh IV, 6, 3 i noweli Marcjana, uznać należy, iż dotyczyła ona też wojskowych. Wcześniej zakazano związków Żydów z chrześcijankami (CTh XVI 8, 6 z 339 r.).

${ }^{47}$ Regulacje przeciwko wyznawcom judaizmu w okresie chrześcijańskim wraz z wcześniejszą literaturą omówił szczególowo A. D e bińsk i, Ustawodawstwo karne..., s. 175-202. Por. też B. Biondi, Il diritto..., s. $348-349,354 ;$ M. K as er, Das römische..., t. II, s. 168; K. L. Noethlichs, Die gesetzgeberischen..., s. 46 i n.; G. De B onfilis, Legislazione ed Ebrei nel 4 secolo. Il divieto dei matrimoni misti, Bullettino dell'Istituto di Diritto Romano Vittorio Scialoja 1987, 90, s. 389-438; G. L. Falchi, La legislazione imperiale circa $i$ matrimoni misti fra christiani ed ebrei nel secolo $V$, [w:] Accademia Romanistica Costantiniana. VII Convegno 1985, Napoli, Perugia 1988, s. 203-212; A. M. R a bello, Il problema dei matrimoni fra ebrei e cristiani nella legislazione imperiale $e$ in quella della Chiesa (IV-VI secolo), [w:] ihidem, s. 213-224; D. T a m m, Roman Anti-jewish Legislation and Adversus-judaeos Literature, Tijdschrift voor Rechtsgeschiedenis 1992, 60, s. 177-184.

48 Por. H. Insadowski, Rzymskie prawo..., s. 215; A. D e binski, Ustawodawstwo karne..., s. $184-185$.

${ }^{49}$ Por. np. Th. M omm s e n, Römisches..., s. 698 699, H a rım a n n, s.v. Adulterium, [w:] RE I, col. 432-435; G. F. Falchi, Diritlo penale romano, t. II, Padova 1932, s. 107 i n.; A. Berger, Encyclopedic..., s. 352; E. Levy, Gesetz und Richter im Kaiserlichen Strafrecht. Erster Teil. Die Strafzumessung, [w:] Gessammmelte Schriften, t. II, s. 500; B. B i o n d i, La poena adulterii da Augusto a Giustiniano, [w:] Scritti giuridici, 1. II, Milano 1965, s. 47 i n.; A. D ę bi ński, Ustawodawstwo karne..., s. 186.

${ }^{50}$ D. 48,5 .

${ }^{51}$ Od Justyniana Wielkiego kobieta była karana lagodniej. Por. Institutiones Iustiniani 4, 18 , 4 (ed. Corpus Iuris Civilis, t. I, recognovit P. Krueger, Berlin 1954; thum. C. Kudnerewicz, Instytucje Justyniana, Warszawa 1986); Nov. lust.: 117, 8 z 542 r.; 134, 10 z 556 r.

${ }^{52}$ CTh XI, 36, 4 z 339 r.. Por. A. Dębińsk i, Sacrilegium w prawie rzymskim, Lublin 1995, s. $137-139, z$ dalszą literaturą.

${ }^{53}$ Por. konstytucje zebrane w CTh IX, 38.

${ }^{54} \mathrm{~W}$ postaci ukrzyżowania (zakazanej pod wpływem chrześcijaństwa już za Konstantyna Wielkiego i zastąpionej karą in furcam tollere oficjalnie dopiero za Justyniana I Wielkiego) 
Dux zatem, pomimo zawarcia małżenstwa z Żydówką, karany byłby łagodniej. Związki przedstawicieli warstw uprzywilejowanych (i to niezależnie od tego, czy byli oni poganami czy chrześcijanami) z kobietami pochodzenia żydowskiego musiały być niezwykle rzadkie ze względu na odmienność kulturową. Jak wspomniano wyżej, wśród warstw uprzywilejowanych późnoantycznego społeczeństwa rzymskiego powszechna była tendencja do zawierania małżeństw we własnym kregu.

3.4. Wojskowi w stopniu $d u x$ będący katolikami mogli natomiast zawierać małzeństwa $z$ heretyczkami i pogankami. Prawo rzymskie bowiem nigdy nie zakazało malżeństw między prawowiernymi chrześcijanami a heretykami czy poganami lub apostatami ${ }^{55}$. Poza edyktem Leona I z 472 r. dozwalającym na zerwanie zaręczyn między osobami różnych wyznań, ze względu na możliwe konflikty na tle religijnym w rodzinie ${ }^{56}$, prawo rzymskie nie podejmowalo kwestii małżeństw mieszanych między chrześcijanami czy poganami. Uznawano, zwłaszcza w okresie poklasycznym, iż rodzina winna dostarczać państwu nowych obywateli ${ }^{57}$. Herezja czy wyznawanie kultów

i rzucenia na pożarcie dzikim zwierzętom - datio ad bestias (zakazanej pod wpływem chrześcijaństwa także za Konstantyna Wielkiego). Wobec honestiores nie stosowano też kar polegających na pracach przymusowych - opus publicum i opus metalli oraz innych kar cielesnych. Powszechniej stosowano natomiast wobec nich $w$ to miejsce karę wygnania $\mathrm{w}$ formie deportatio in insulam i relegatio oraz kare konfiskaty majątku i inne kary majątkowe. Por. Th. M o m m s en, Römisches..., s. 1033 i n.; U. B r a s i ell o, La repressione..., s. 449 i n.; G. F. Falchi, Diritto penale..., t. I, Padova 1937, s. 70 i n.; F. M. De $\mathrm{Robertis,} \mathrm{La} \mathrm{variazione} \mathrm{della} \mathrm{pena} \mathrm{in} \mathrm{diritto} \mathrm{romano} I I$ : La variazione pro qualitate personarum, Bari 1951, s. 81-134; J. A. R. Korsunski, 'Honestiores'..., zwlaszcza s. 85 i n.; A. H. M. Jones, Studies..., s. 64-65; te nże, The Later..., s. 17-18, 519, 749-750; A. Demandt, Geschichte der Spätantike. Das Römische Reich von Diocletian bis Justinian 284-565 n. Chr., München 1998, s. 241-242; R. R ilinge r, Humiliores - Honestiores. Zur einer sozialen Dichotomie im Strafrecht der römischen Kaiserzeit, München 1988 (podważającego zasadność stosowania tego podziału).

"s Zob. H. Insad owski, Rzymskie prawo..., s. 215-216. W końcu IV w. stosunkowo częste musiały być przypadki apostazji, skoro panujący ograniczali pozycję prawną odstępców; por. konstytucje zebrane [w:] CTh XVI, 7 = ze zmianami C I, 7. Por. też K. Z a krzewski, Rzq̨dy i opozycja za cesarza Arkadjusza, Kraków 1927, s. 52 i n.

${ }^{56} \mathrm{C} \mathrm{V}, 1,5,3$. $\mathrm{Na}$ jej temat por. C. St. Tomule scu, Léon ler et le droit privé, [w:] Accademia Romanistica Costantiniana. Atti del $V$ Convegno, Perugia 1983, zwłaszcza s. 59-61. Na temat ustawodawstwa tego cesarza por. A. S. S c a r cella, La legislazione di Leone I, Milano 1997. Por. też skrótowe ujęcie J. Gau de $\mathrm{met}, L$ Ĺnglise dans l'empire romain (IVe-Ve siècles), Paris 1958, s. 525-526.

${ }^{57}$ Por. B. Ła picki, O spadkobiercach ideologii rzymskiej. Okres chrystianizacji cesarstwa rzymskiego, Łódź 1962, s. 181-187, 269-271 i 285-286; J. 11 u k, Chrześcijańskie malżeństwo..., s. 237. 
niechrześcijańskich nie były też nigdy uznanymi prawnie przesłankami rozwodu ${ }^{58}$.

4.1. $Z$ formalnego punktu widzenia, obywateli rzymskich obowiązywały też zakazy małżeństw $\mathrm{z}$ barbarzyńcami.

Około 370 r. mieszkańcom prowincji zakazano zawierania małżeństw z kobietami barbarzyńskiego pochodzenia oraz barbarzyńcom z Rzymiankami $^{\text {59 }}$. Adresatem konstytucji cesarskiej wprowadzającej ten zakaz byl Teodozjusz, magister equitum Walentyniana I panującego w zachodniej części cesarstwa $^{60}$. Wyraźnie poświadcza to, iż konstytucja ta dotyczyła nie tylko mieszkańców prowincji, lecz i oficerów oraz żołnierzy. Nie wiadomo, jak długo ustawa obowiązywała. Najpóźniej od 438 r., wraz z zamieszczeniem jej w Kodeksie Teodozjańskim, zakaz dotyczył wszystkich obywateli rzymskich ${ }^{61}$ i z pewnością barbarzyńców w slużbie rzymskiej ${ }^{62}$. Za złamanie tego zakazu grozila kara śmierci. Konstytucję tę przeniesiono do leges romanae barbarorum, opierających się na kodyfikacji teodozjańskiej, lecz sporne jest zagadnienie

\footnotetext{
${ }^{5 k}$ Nov. Iust.: 22 z 536 r.; 117 z 542 r.; por. też Nov. Iust. 109 c. 1 z 541 r. Patrz na ten temat też K. Visk y, Le divorce dans la legislation de Justinien, RIDA 1976, 23, s. 239-264: O. Vannucchi Forzieri, La legislazione imperiale del 4-5 secolo in tema di divorzio, Studia et Documenta Historiae et Iuris 1982, 48, s. 289-317.

s9 Konstytucja Walentyniana I i Walensa z ok. 370 r. (raczej z 372-373 r.) - CTh III, 14, 1. Por. na temat tej regulacji obszerny artykuł, wraz $z$ wcześniejszą literaturą przedmiotu: M. B i n chin i, Ancora in tema di unioni tra barbari e romani, [w:] Accademia Romanistica Costantiniana. VII Convegno, 1985, Napoli, Napoli 1988, s. 225-249. Por. też H. I n sadowski, Rzymskie prawo..., s. 215-216; M. Kaser, Das römische..., t. II, s. 164; J. H. G. W. Li e beschuet z, Barbarians and Bishops. Army, Church and State in the Age of Arcadius and Chrysostom, Oxford 1990, s. 13.

${ }^{60}$ Por. PLRE I, s. 902-904, s.v. Flavius Theodosius 3.

${ }^{61}$ Por. M. Bianchini, Ancora..., s. 226-229. J. Harries, Law and Empire in Late Antiquity, Cambridge 1999, s. 24-25. O jej powszechnym obowiązy'waniu świadczy też fakt umieszczenia konstytucji w Kodeksie Teodozjanskim, w ponad 50 lat po jej wydaniu. Kodeks ten obowiązywal tak we wschodnim jak $\mathrm{i}$ w zachodnim cesarstwie. Por. studium G. G. A r chi eg o, Teodosio II e la sua codificazione, Napoli 1976, oraz z nowszej literatury zbiór artykułow: The Theodosian Code. Studies in... Odmiennie i błędnie, ze zakaz ten obowiązywał tylko w zachodniej części państwa rzymskiego - W. Li te wski, Rzymskie prawo prywatne, Warszawa 1994, s. 127 i 160; te nże, Slownik encyklopedyczny..., s. 28. Przesłanki polityczne wydania tej regulacji skrótowo objaśnia J. Ilu k, Chrześcijańskie malżeństwo..., s. 236, p. 43. Dekret ogłoszono w czasach umacniania przez Walentyniana I granicy nad Renem.

${ }^{62}$ M. B i a n chini, Ancora..., s. 226-229. Por. też A. De m and l, The Osmosis..., s. 77. Autor ten jest zwolennikiem szerokiego zakresu podmiotowego tej regulacji; inni uczeni odnoszą go tylko do barbarzyńców służących w armii rzymskiej.
} 
jej obowiązywania w zachodniej Europie po $476 r{ }^{63}$ Nie znalazła się ona natomiast w Kodeksie Justyniańskim.

A zatem, w pewnym okresie - od okolo 370 r. i po 438 r. - duces nie mogli zawierać małżeństw mieszanych $\mathrm{z}$ barbarzyńcami. Znamienne jest zamieszczenie tej regulacji w Kodeksie Teodozjańskim, w którym spełniała ona rolę odseparowania arian (z reguly wówczas Germanów) od społeczności katolickiej ${ }^{64}$. Prawo to nie służło (jak to przedstawiano we wcześniejszej literaturze), do ochrony ,rzymskiej krwi” czy rzymskiej kultury przed barbarzyńcami ${ }^{65}$. Pochodzenie regionalne $i$ etniczne nie mialo wówczas niemal znaczenia dla kariery wojskowej. Barbarzyńcy bardzo często osiagali wysokie stopnie oficerskie ${ }^{66}$ - już najpóźniej od czasów Konstantyna Wiel-

${ }_{63}^{63}$ Por. E. De mouge ot, Le conubium dans les lois barbares du Vle siècle, [w:] Recueil de mémoires et travaux publiés par la societé d'histoire du droit et des etudes institutions des anciens pays de droit écrit 1983,12 , s. 69-82.

${ }^{o}$ Odmienne H. Insadowski, Rzymskie prawo..., s. 215-216, który uważał, że przepis ten nie odnosił się do różnicy religii.

${ }^{65}$ Takie stanowisko prezentował A. Piganiol (L'Empire Chrétien, Paris 1947, s. 193) a za nim np. J. G a udemet (Aspects politiques de la codification théodosien, [w:] Instituzioni Giuridiche e realtà politiche nel Tardo Impero (III-V sec. d. C.). Atti di un incorso tra Storici e Giuristi, Firenze, 2-4 Maggio 1974, a cura di G. G. Archi, Milano 1976, s. 267-268). M. Bianchini (Ancoro..., s. 238 i n.), słusznie skrytykowała to stanowisko. Por. na temat zagadnienia związków małżeńskich między Germanami a Rzymianami szersze studium R. S or a ci, Ricerche sui conubia tra Romani e Germani nei secoli IV-VI, Catania 1974.

${ }^{66}$ Różnorodność pochodzenia etnicznego uwidoczniona jest $\mathrm{w}$ biogramach dowódców tego stopnia. Por. ich najpełniejsze zestawienie [w:] PLRE. Nie oznacza to jednak, aby większość stanowisk dowódczych $w$ armii późnorzymskiej obejmowali barbarzyńcy. Oficerowi pochodzenia rzymskiego byli zawsze $w$ większości. Stopień barbaryzacji zależał również od rodzaju oddziałów, był wyższy $w$ armii polowej - comitatenses, a zwłaszcza $w$ pozostających do bezpośredniej dyspozycji cesarza praesentales, niższy zaś w oddziałach prowincjonalnych - limitanei. Por. m. in. J. Ka ray a n opulos, Die Entstehung der byzantinischen Themenordnung, München 1959, s. 40 i n., 73-74; A. H. M. Jones, The Later.., s. 388 i n. oraz 622-623; J. L. Te a 11, Barbarians in Justinian's Armies, Speculum 1965, 40, s. 294-323; J. H. W. G. Liebeschuetz, Barbarians..., s. 7-153 (w tym na temat barbarzyńców wśród duces s. 15); P. S outhern, K. R. D ix on, The Late Roman..., s. 46-52, a zwłaszcza s. 50 i 71; H. Elton, Warfare in Roman Empire AD 350-425, Oxford 1996, s. 128-151 (w tym tabele i wykresy porównujące liczbę oficerów rzymskiego i barbarzyńskiego pochodzenia w latach 350-425). Patrz też J. Wi e wi or owski, Moesiae... Z zestawienia tego wynika, że na znanych przypuszczalnie 17 dowódców w stopniu $d u x$ w prowincjach Moesia Secunda i Scythia Minor, tylko czterem przypisać można, z zastrzeżeniami, barbarzyńskie pochodzenie. Jak wykazano ostatnio (A. Cameron, J. Long with a contribution by L. Sherry, Barbarians and politics at the court of Arcadius, Berkeley, Los Angeles, Oxford 1993, zwłaszcza konkluzje s. 323 i n.), rola resentymentów narodowych i procesów barbaryzacji armii późnego imperium była $w$ historiografii często przeceniana. Germanizacja korpusu oficerskiego występowała $\mathrm{w}$ większym stopniu na Zachodzie, zwłaszcza za dynastii teodozjańskiej; por. R. C. Blockley, [w:] CAH, t. XIII, s. 111-112. 
kiego $^{67}$. Dotyczyło to również oficerów w stopniu dux. Barbarzyńcy bardzo łatwo ulegali przy tym asymilacji, co związane bylo $z$ atrakcyjnością kultury i cywilizacji rzymskiej. Nie znamy przykładów powrotu oficerów nierzymskiego pochodzenia $w$ strony rodzinne, poza granice imperium, po zakończeniu shużby. Barbarzyńcy osiągali prawdopodobnie status obywateli rzymskich, o czym świadczy przejmowanie przez nich odcesarskiego imienia Flavius ${ }^{68}$. Nadal traktowani byli jednak przez Rzymian jako obcy, a później także jako ariańscy odstępcy ${ }^{69}$.

Mimo zakazu małżeństw mieszanych często w związki takie wchodzili barbarzyńcy - zwłaszcza w okresie wzmożonego osadnictwa germańskiego na ziemiach cesarstwa, od końca IV w. żeniący się z Rzymianami Germanie ${ }^{70}$. Małzeństwa takie były powszechne wśród grupy wyższych wojskowych, do której należeli dowódcy $\mathrm{w}$ stopniu dux i to niezależnie od pochodzenia etnicznego samych oficerów.

${ }^{67}$ Por. Th. Mommse n, Das römische Heerwesen seit Diocletian, Hermes 1889, 24, s. 239 i n.; A. H. M. Jones, The Later..., s. 135; G. Alföldy, Historia spoleczna..., s. 249 i 259; E. Demougeot, La formation de l'Europe et les invasions barbares, p. II, Paris 1979, s. 845 i n.; J. Kolend o, Kontakty Rzymu z barbarzyńcami Europy Srodkowej $i$ Wschodniej, [w:] Starozytny Rzym we wspolczesnych badaniach, Liber in memoriam L. Piotrowicz, Kraków 1994, s. 229; P. Veyne, Humanitas, [w:] Czlowiek Rzymu, red. A. Giardin, Warszawa 1997, s. 421-450.

${ }_{68} \mathrm{Na}$ temat popularności i znaczenia odcesarskicgo nomenu gentile - praenomenu Flavius w późnym antyku por. G. Alföldy, Die Personennamen in der romischen Provintz Dalmatia: Beiträge zur Namenforschung, Heidelberg 1969, s. 46 i n., 181; A. M ócsy', Der Name Flavius als Rangbezeichnung in der Spätantike, [w] Akte des IV. Internationaten Kongreßes für grieschiche und lateinische Epigraphik (Wien, 17. bis 22. Sept. 1962), Wien 1964, s. 257-263; J. G. Ke en en, The Name Flavius and Aurelius as status designations in Later Roman Egypt, ZPE 1973, 11, s. 33-63 i ZPE 1974, 13, s. 283-304.

${ }^{6 y}$ Por. J. H. G. W. Li ebeschuet z, Barbarians..., s. 22; A. De m a nd t, Geschichte..., s. 237

${ }^{70}$ Por. M. Bianchini, Ancora..., s. 226-229 oraz ustalenia prozopograficzne i genealogiczne na temat związków między elitami germańskimi a Rzymianami, przedstawione u nowszych autorów, m. in. przez: M. W a a s (Germanen im römischen Dienst (im. 4. Jh. n. Chr.), Bonn 1971); W. R a u a (Die römischen Heermeister des 4. Jahrhunderts n. Chr. (mit einer prosopographischen Dokumentation), Nürnberg 1974); A. Demandta (Der Spätrömische Militäradel..., s. 609-637, zwłaszcza tablica geneaologiczna); A. Sch wa r c za (Reichsangehörige Personen Gothischer Herkunft. Prosopographische Studien, (diss., maszynopis), Wien 1984), ponownie A. Demandta (The Osmosis..., zwłaszcza tablica genealogiczna rozbudowana wobec opublikowanej wcześniej [w:] Der Spätrömische Militäradel...). Według lego ostatniego autora, związki między elitami germańskimi i rzymskimi pozwalają stwierdzić, że teoretyczna koncepcja F. Dölgera na temat bizantyńskiej ,rodziny królów” była faktem historycznym w okresie późnego antyku (w pełnym kształcie przedstawiona [w:] F. Dölge r, Die "Familie der Könige" im Mittelalter, Historisches Jahrbuch 1940, 60, s. $397-420=$ te nż e, Byzanz und europäische Staatenwelt. Ausgewählte Vorträge und Aufsätze, Ettal 1953 (reed. Darmstadt 1964), s. 34-69). Na temat teorii F. Dölgera krytycznie wypowiedzial się m. in. E. Ch r y's o s (Legal Concepts and Patterns for Barbarian Settlement on Roman Soil, [w:] Das Reich und die Barbaren, hrsg. v. E. K. Chrysos, s. 13-24). 
4.2. Justynian I wprowadził zakaz małżenstw mieszanych $w$ prowincji Osroene, na pograniczu perskim ${ }^{71}$. We wstępie do noweli odwołano się do nie wymienionych $\mathrm{z}$ nazwy wcześniejszych zakazów prawa rzymskiego - tak starych, jak i nowych.

Regulacja ta obowiązywała wszystkich mieszkańców prowincji, niezależnie od ich pozycji spolecznej ${ }^{72}$. Odróżniała ona tych, którzy przed jej wydaniem pozostawali w zakazanych związkach małżeńskich, od tych, którzy w związki takie wstapili po jej wydaniu. Wobec pierwszych przewidywano kary finansowe, drugim, a także ich żonom i dzieciom - grożono karą śmierci i konfiskatą majątku. Odpowiedzialnymi za ogłoszenie i przestrzeganie zakazu byli cywilni i wojskowi zarządcy prowincji. Regulacja ta służý miała jako środek nadzwyczajny przeciwdziałaniu zbierania informacji przez państwo perskie ${ }^{73}$. Nowela skierowana była do comitis sacrarum rerum privatarum, który - wedhug sformulowania W. Enßlina - zarzqdzal on rozleglymi domenami państwowymi, z których czesśś byla wydzielona na wylaczny uzytek dworu; mial on też pod opieka prywatnq kase cesarsk ${ }^{74}$. Urzędnik ten nie miał natomiast żadnych uprawnień w stosunku do wojskowych $^{75}$.

Jak wskazano wyżej, nie można wykluczyć, iż regulacja ta, skierowana do urzędnika cywilnego, dotyczyła także żołnierzy. Wprowadzony w noweli zakaz mógł obowiązywać żołnierzy wojsk prowincjonalnych (limitanei). $\mathrm{W}$ tym okresie $\mathrm{z}$ pewnością uprawiali oni ziemię $\mathrm{w}$ prowincjach $\mathrm{i}$ zamieszkiwali w nich na stale ${ }^{76}$. Żolnierze armii późnorzymskiej z pewnością podlegali zarządcom wojskowym prowincji, a w czasach justyniańskich

"Nov. Iust. 154 (nie datowana). Osroene (łacińska nazwa Osthoene) to obecna część zachodniej Turcji, północno-zachodnia Mezopotamia.

${ }^{72} \mathrm{~W}$ tekście noweli użyto ogólnego sformułowania, iż dotyczy ona osób przebywających

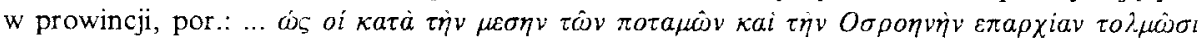

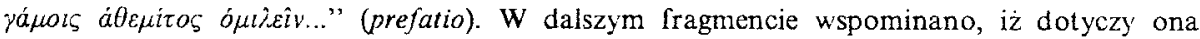
wszystkich, niezależnie od stanowiska i majątku.

${ }^{73}$ Por. A. Demandt, The Osmosis..., s. 77.

${ }^{74}$ W: N. H. Baynes, H. St., L. B. Moss, (opracowanie), Bizancjum. Wstep do cywilizacji wschodniorzymskiej, przełożył̇ E. Zwolski, Warszawa 1964, s. 251.

${ }^{75}$ Por. obszerne studium R. Del in a ire, Largesses sacrés et 'res privata'. L'aerarium impérial et son administration du IV au VI siècle, Collection de l'École Française de Rome 121, Roma 1989, s. IX + 759. Zagadkowy pozostaje fakt, dlaczego adresatem noweli był zarządca domen cesarskich, a nie - jak być powinno w przypadku aktów dotyczących mieszkańców kilku prowincji $w$ czasach justyniańskich -- praefectus praetorio odpowiedniej części państwa (w przypadku terenów bliskowschodnich praefectus praetorio per Orientem).

${ }^{76}$ Por. B. Is a ac, The Meaning..., podsumowujący dotychczasowe na ten temat poglądy w literaturze. We wcześniejszym piśmiennictwie sugerowano, iż byli oni żołnierzami-rolnikami już od IV w., podczas gdy pierwsze pewne żródła potwierdzające uprawę ziemi przez limitanei pochodzą $\mathrm{z}$ połowy $\mathrm{V}$ w. Por. też $\mathrm{P}$. Souther, K. R. Dix on, The Late Roman..., s. 36. 
cywilni gubernatorzy uzyskali jurysdykcje wobec żolnierzy ${ }^{77}$. W szeregu prowincji Justynian I wprowadził też zarząd prowincjonalny skupiający całość władzy cywilnej i wojskowej w ręku jednego administratora ${ }^{78}$. Analizowana nowela nie dotyczyła jednak oficerów w stopniu dux, gdyż nie byli oni mieszkańcami prowincji. Po upływie okresu służby na stanowisku dowódcy prowincjonalnego, wynoszącego zazwyczaj kilka lat ${ }^{79}$, oficerów przenoszono na inne stanowisko, awansowano ${ }^{80}$ lub $w$ ogóle zwalniano ze shużby ${ }^{81}$.

5. Omówione ograniczenia swobody zawierania malżeństw obowiązywały dowódców w stopniu $d u x$, jako oficerów rzymskich i obywateli Imperium. Zakazy małżeńskie znane $w$ tradycji rzymskiej były początkowo pojmowane jako brak conubium.

W okresie późnoantycznym ulegały one przekształceniu w zakazy małżeńskie zbliżone do pojęcia impedimentum matrimonii, czyli okoliczności,

"Gubernator postrzegany był jako strażnik prawa w prowincji, także wobec żotnierzy (por. C I, 40, 12). W przypadku naruszeń przez nich prawa obowiązany był jedynie do zatrzymania sprawcy takiego naruszenia i powiadomienia wyższego oficera $w$ stopniu magistri militum (por. CTh IX, 22 z $365 \mathrm{r}$. = C IX, 3, 1; Novella Theodosiani 7. 1, 2 (ed. $\mathrm{CTh}$, t. II) = C III, 23, 2). Za Justyniana I wzmocniono pozycję gubernatorów wobec żotnierzy (Nov. Iust. 8 , c. 12 i 13 z 535 r.).

${ }^{78}$ Obok występujących już wcześniej wyjątkowych przypadków. Patrz: Nov. Iust.: 8, c. 2, 3 i 5; 24-31; 102-103; Edictum Iustiniani 4 i 13, c. 1, 2, 19, 23. Na temat reform administracyjnych za Justyniana I por. $\mathrm{m}$. in.: Ch. Diehl, Justinien et la civilisation byzantine au Vle siecle, Paris 1901 (reed. New York 1969), s. 270 i n.; A. H. M. Jones, The Later..., s. 282 i n.; J. Karaya nnopulos, Die Entstehung..., s. 62 i n. Dobre, generalizujące podsumowanie reform przedstawił też T. F. Carney, Bureaucracy in Traditional Society. Roman-Byzantine Bureaucracies viewed from Within, Coronado Press, b. d., Book 2, s. 157-159.

${ }^{79}$ A. H. M. Jones (The Later..., s. 381), wymienia listę ośmiu duces w Egipcie z lat 339-368, $z$ których dwóch pierwszych sprawowało urząd 5 lat, a pozostali 3 lata.

${ }^{80}$ Awans ducis na wyższe stanowiska $w$ armii był w IV w. raczej rzadkością; por. A. H. M. Jones, The Later..., s. 390. Przykładem niespodziewanego awansu jest kazus cesarza Teodozjusza I, sprawującego w latach 373-374 urząd ducis Moesiae primae, a następnie powołanego na współpanującego przez cesarza Gracjana. Por. Ammianus Marcellinus, Res Gestae, XXIX 6, 5.

${ }^{* 1}$ Prawie nie znane są bliższe szczególy na temat ich losów po okresie służby; por. A. H. M. Jones, The Later.., s. 383 p. 39. Patrz też biogramy znanych dowódcow $w$ tym stopniu zebrane w: PLRE i dla obszaru dolnodunajskiego J. W ie wi or o w sk i, Moesiae... Po odwolaniu ze stanowiska i ostatecznym zakończeniu służby publicznej były urzędnik nie miał prawa do emerytury. W państwie rzymskim nie istniało takie pojęcie. Były urzędnik miał prawo do posługiwania się ostatnio noszonym tytułem z przydomkiem ex oraz rangą honorową i miał prawo do związanych z nimi przywilejów. Możliwe było również powołanie na fikcyjne wyższe stanowisko, z czym nie musiała się jednak łączyć przynależność do wyższej kategorii honorowej. 
które nie pozwalały zawrzeć ważnego małżeństwa. Zakaz małżeństw z Żydówkami ze względu na różnice kulturowe nie był przez dowódców w stopniu dux naruszany. Oficerowie ci jednak nie przestrzegali prawdopodobnie też zakazu małżeństw z kobietami „niegodnymi”. Większość dowódców prowincjonalnych wywodzila się spośród prostych żołnierzy. Dopiero po osiągnięciu stopnia dux $\mathrm{z}$ reguły po kilkudziesięcioletniej służbie, podlegali oni temu zakazowi. Zniknąl on ostatecznie w czasach justyniańskich, pod wpływem chrześcijaństwa. Duces podlegali też w teorii, bezpośrednio od około $370 \mathrm{r}$. i od 438 r., zakazowi małżeństw mieszanych między barbarzyńcami a Rzymianami. Zakaz ten nie był jednak przestrzegany przez przedstawicieli wojskowych i cywilnych elit cesarstwa późnorzymskiego, do których zaliczali się też duces. 